\title{
Fishtail Points, Technology and Microwear Analysis from the Negro River Basin, Uruguay
}

\author{
Hugo G. Nami ${ }^{1}$, Alicia Castro ${ }^{2}$ \\ ${ }^{1}$ CONICET-IGEBA, Laboratory of Geophysics “Daniel A. Valencio”, Department of Geological Sciences, FCEN, \\ UBA, Ciudad Autónoma de Buenos Aires, Argentina \\ ${ }^{2}$ Scientific Department of Archaeology, Faculty and Museum of Natural Sciences, UNLP, Paseo del Bosque s/n. \\ Buenos Aires (1900), Argentina \\ Email: hgnami@fulbrightmail.org, acastro@fcnym.unlp.edu.ar
}

Received 20 May 2014; revised 25 June 2014; accepted 8 July 2014

Copyright (C 2014 by authors and Scientific Research Publishing Inc.

This work is licensed under the Creative Commons Attribution International License (CC BY).

http://creativecommons.org/licenses/by/4.0/

(c) ()

\begin{abstract}
Ongoing research performed in the central part of Uruguay added new Paleo-Southamerican finds from the Negro River basin. A number of lithic exemplars were analyzed to determine their technology and function. The examined artifacts provided a new perspective on Fisthail points. Microwear analysis showed that there is a difference in the location of microscopic polishing between the blade and stem in the examined points. Polishing in the stem's border might be attributed to leather or a similar substance, probably the leather cord or sinew used to bind the points in the foreshaft. The surface of the stem shows a coarse micro-topography and has patches of black residues. The coarse micro-topography suggests the use of an adhesive substance covering the whole stem, while the black patches are probably the residue used to glue the points in the foreshafts. Most remarkable is the discovery of the use of edge-to-edge and overshot flaking for bifacial reduction, technical features shared with Paleoindian fishtailed points from North and Central America.
\end{abstract}

\section{Keywords}

Fishtail Points, Lihic Technology, Microwear Analysis, South America, Southern Cone, Uruguay

\section{Introduction}

Recent investigations performed in the central part of Uruguay have added new Paleo-Southamerican finds from 
the Negro river basin. Fishtail points were found along with other likely Paleoindian specimens. They were found at the Los Espinillos and El Puente sites (LE and EP hereafter). EP $\left(32^{\circ} 49^{\prime} 23.67^{\prime \prime S}, 56^{\circ} 29^{\prime} 56.05^{\prime \prime} \mathrm{W}\right)$ is located in Centenario village at about $100 \mathrm{~m}$ east from the 5 road bridge on the river; LE (32 $50^{\prime} 52.97^{\prime \prime} \mathrm{S}, 56^{\circ} 24^{\prime}$ 47.99"W) is located at about $4 \mathrm{~km}$ north of the Minas de Callorda site, both in the Durazno department (Figure 1). At EP there is a relict of an alluvial deposit consisting of a sandy gray layer overlying a Late Pleistocene pale brown sandy clay which is similar to that observed at other sites in the area (Nami, 2013). Both places yielded archaeological remains on surface (mostly flakes) which originated from the erosion caused by the river's level fluctuations on the riverbanks deposits. Two unequivocal Paleoindian fishtail or Fell projectile points are among the surface finds. They represent an excellent marker to know the presence of early hunter-gatherers populations living during the end of the Pleistocene and its transition to the Holocene at about 11,000 - 10,000 uncalibrated radiocarbon years before present (Nami, 2007); also found a very well made biface of probable Paleoindian origin. The function and technology of these artifacts were examined to gather information on Paleo-South American practices. A previously reported fishtail point from the Arroyo Cacique site (AC, Nami, 2007: figure 4(a), 2013: figure 4 (i)) was also subjected to functional analysis. In addition, detailed observations of two Fell points recently analyzed are also described from a technological and morphological perspective. One of them was found in the vicinity of the Baygorria dam (BD) in the Río Negro department; the other one was recovered from the excavation of a foundation well in the Paraje Tejera (PT) at $15 \mathrm{~km}$ from Durazno city in the homonymous department. Resulting from this research, this paper reports additional data to gain a deeper understanding of the technology and function of the Paleo-South American lithic assemblages from the Negro river basin, Uruguay.

\section{Analysis and Observations}

A brief description of each piece follows, with dimensions (length, width, and thickness in $\mathrm{mm}$ ) in parentheses. EP $(35.8 \times 19.9 \times 5.6)$ is a red chert Fishtail stemmed point; the stem length 15.7, width 14.1 and $16.9 \mathrm{~mm}$ in the center and base respectively (Figure 2(a)). Base thinned by deep retouches of almost the length of the stem rangs between about $7-11 \mathrm{~mm}$ on one side and up to $13 \mathrm{~mm}$ on the other. It shows a non regular pressure flaking pattern. The flake-blank used for its manufacture is evident by the remains of its ventral face, visible in the upper right part of the reverse face. It is made on a high quality red rock (probably a silcreta from the Queguay formation) similar to Chuska chert from Colorado, USA. Texture and brightness might suggest that the raw material was subjected to heat treatment, such as has been experimentally observed in similar rocks from the area (Nami, 2010). LE $(30.5 \times 20.9 \times 7.2)$ is made from very good quality homogenous pale brown chert (Figure 2(b)). Starting at the tip, it shows a flake scar ending in step fractures, possibly produced by impact. The blade is $14 \mathrm{~mm}$ long and the stem is 20.3 long by 17.4 and $19.8 \mathrm{~mm}$ wide in the middle and base respectively. The stem base was thinned by short pressure retouches less than $5 \mathrm{~mm}$ in deph; however one deeper retouch of about 14 $\mathrm{mm}$ length by $7 \mathrm{~mm}$ wide was applied. Both points show that the stem edges are highly abraded, a usual feature

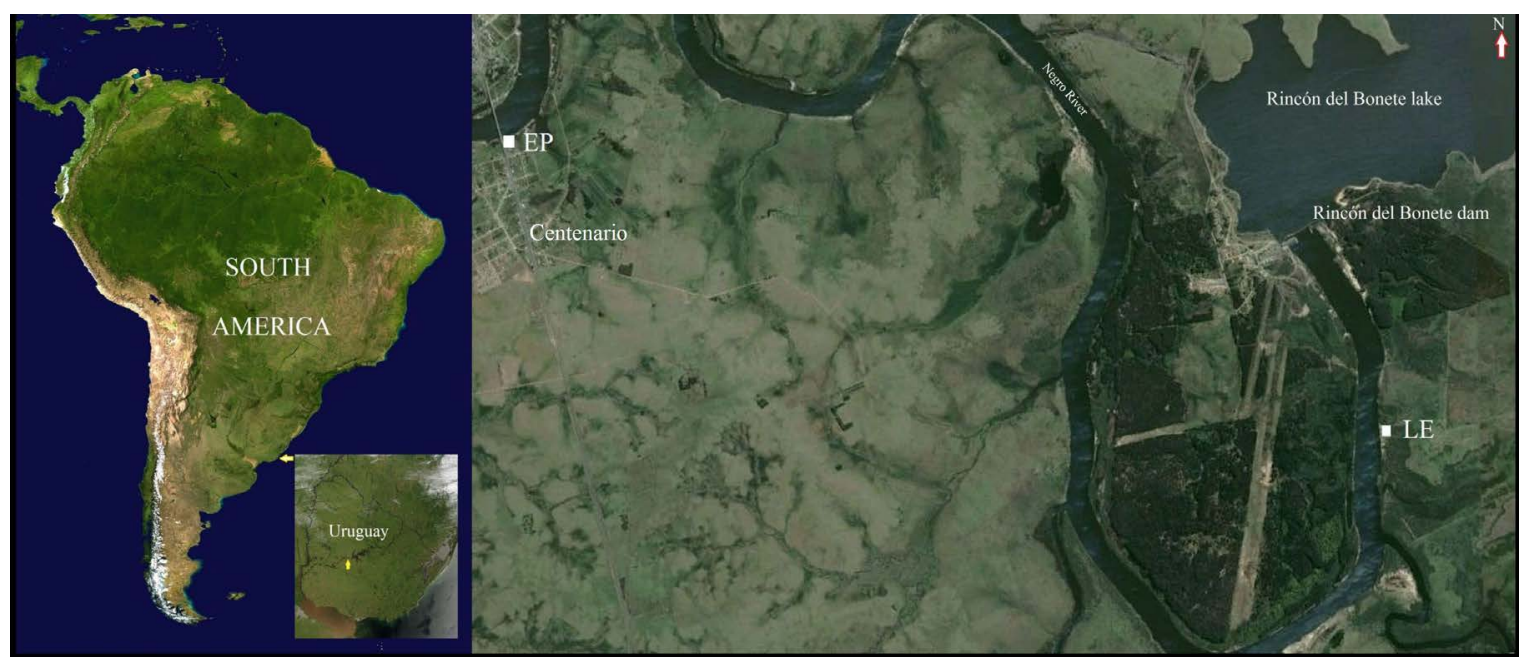

Figure 1. Map of South America and the location of El Puente (EP) and Los Espinillos (LE) sites in the middle Negro river area which is pointed with an arrow in the map of Uruguay (after Google Maps, 2014). 


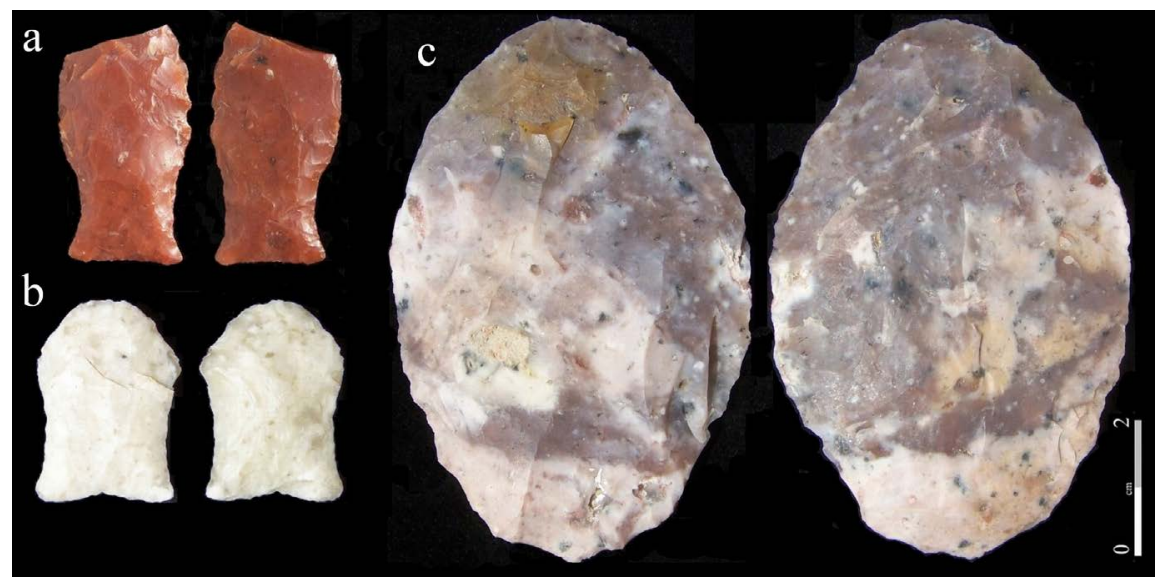

Figure 2. (a)-(c) Obverse and reverse views of the new by Paleo-South Americans specimens reported in this paper. Fishtail points from EP (a) and LE (b); (c) biface from LE.

of fishtail specimens. EP exemplar exhibits a fracture that removed the third distal part of the blade and LE suggests that its body was strongly resharpened until its minimum expression and does not have enough mass to bear continued use, and for this reason it was probably discarded. This practice also occurred with the fishtail points from AC (Nami, 2009: figure 1 (A), 2013: figure 4 (o)) and Minas de Callorda sites in Uruguay (Nami 2007: figure 1 (A), 2013: figure 4(f)), and other places in South America (Nami, 2014). The condition of both projectile points suggests that they were probably brought to the site on foreshafts and discarded after use. Figure 3(a) depicts the specimen from the BD; it is a complete Fell point $(47.4 \times 22.8 \times 6.2)$ chipped from a brown chert, similar to those found in secondary sources existing in the region and identified in the Rincón del Bonete dam (Nami, 2007); the stem length is $19.0 \mathrm{~mm}$ and the base wide is $15.4 \mathrm{~mm}$. As usual, the stem's borders showed abrasion. The base was thinned by short and deep retouches of almost the length of the stem. It shows a marginal pressure retouch applied on a bifacial blank that remarkably shows the use of edge-to-edge and/or overshot percussion flaking strategy, also identified in other pieces from Uruguay; for instance the specimens found at Merin lagoon, Rocha department (Figure 3(b)). Additionally, in fishtail manufacture, this particular method was recognized at the Ilaló region, Ecuador (Nami, 2014). That is to say, it is important to recall that this kind of flaking tactic was widespread in North America during Paleo-American times (Stanford \& Bradley 2012). In Central and northern South America it was also identified in preforms and thinning flakes from Panama and Venezuela (Cooke \& Sánchez, 2003; Pearson \& Ream, 2005). The fishtail from PT (59.2 × 89.5 × 6.5) is seen in Figure 3(c). This exemplar is a broad blade lacking the lower part of the stem; it is made of an excellent quality brown tone silicified limestone, also an available rock in the area. The blank was nicely thinned by soft bifacial percussion flaking and finished by pressure retouches of $\sim 3-9 \mathrm{~mm}$ wide and varied depths on the faces. It shows flattened uniform biconvex longitudinal and transversal cross-sections, similar to the biface from LE. Despite that the stem is mostly absent, on its lower portion are visible the ends of two long flutes in each face that pass over the blade/stem intersection. Like other Uruguayan exemplars this blade shows fishtails with little or no resharpening that can be observed in the middle Negro river basin and in Fell points from the Rincón del Bonete and Tres Arboles creek areas (Nami, 2013: figure 3 (q), (r), $4 \mathrm{l} \mathrm{m}$ ). This feature is also recognizable in other pieces from Uruguay, such as the specimens exhibited in Figures 3(d)-(f), respectively belonging from Tapia, Canelones department (Bosch et al., 1980; López et al., 2001), the Negro river basin (Bosch et al., 1980) and the Boicuá creek, Salto department (Cordero, 1960).

At LE, along with the Fell point a very well thinned biface $(81.5 \times 55.0 \times 11.5)$ was also found (Figure 2(c)). Following the Callahan (1979) guidelines for biface analysis, the width/thickness ratio is 4.8 and the angle average taken at 5 points around the piece is $39.2^{\circ}$. It has flattened thin biconvex longitudinal and transversal cross sections. The flake removal does not show a regular pattern. The edge is regular and has a relatively moderate lineal offset. Except in a small portion, abrasion is not visible to the naked eye for platform preparation. Plane flake scars suggest that this stage was flaked using soft percussion flaking. While this biface is finely made, some flake scars show step terminations. This analysis indicates that this artifact corresponds to a stage 4 in the bifacial thinning reduction model proposed from an experimental perspective (Callahan, 1979). 


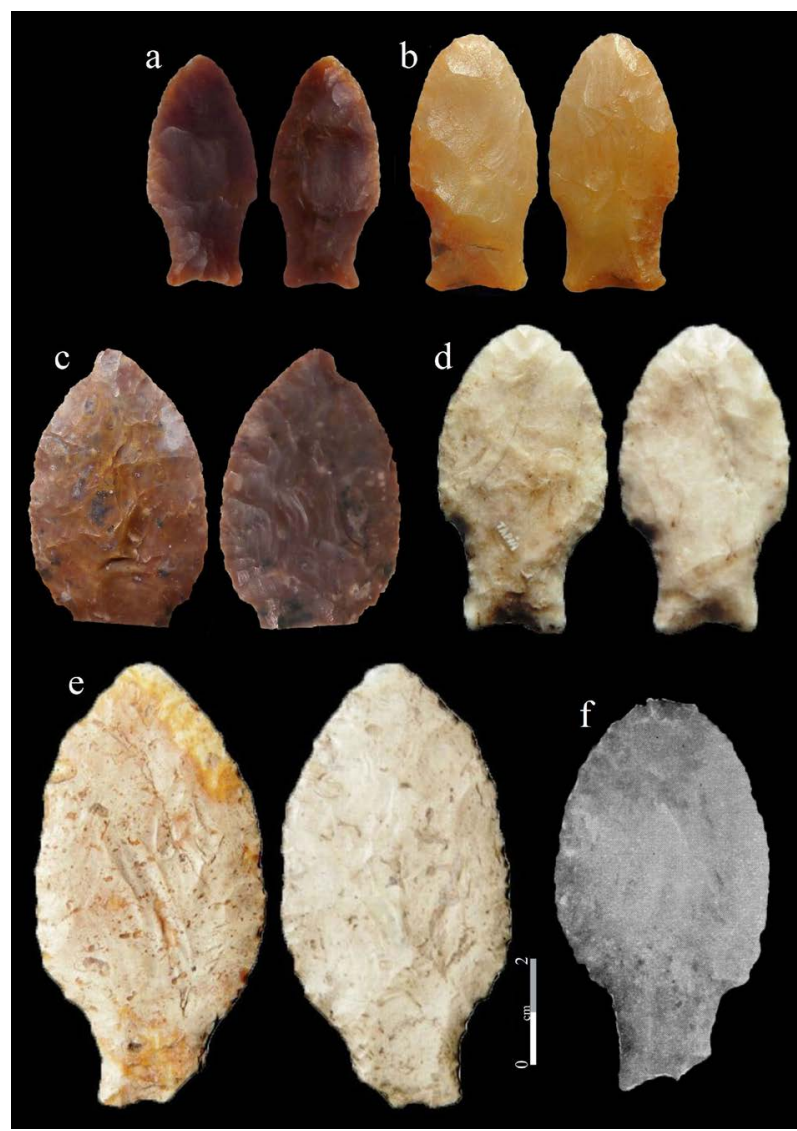

Figure 3. Fishtail points from different Uruguayan locales. (a)-(b) showing edge-to-edge and/or overshot flaking, (c)-(f) With little or absent resharpening. (a) Baygorria dam area; (b) Merin lagoon; (c) Paraje Tejera; (d) Tapia; (e) Negro river; (f) Boicuá creek (not in scale, after Cordero, 1960).

One of our goals in the Fell point studies is to perform functional investigations to gain knowledge about its use. For this reason, following the "high power" approach developed by Keeley $(1976,1980)$ they were microscopically analyzed for use-wear. In this case, polishing intensity and striations were analyzed with a UNION metallographic microscope with magnification between $100 \times$ and $300 \times$. Before being observed in the apparatus, each piece was cleaned with a solution of chlorine and sodium hydroxide for twenty minutes and furthermore washed with detergent and fine alcohol. During the analysis, specimens were manipulated with latex gloves to avoid contamination.

EP point shows a continuous dull, thick and intense polishing in the shoulder and stem's border that might be attributed to leather or a similar material. It shows a similar surface to those left by grease as product of researcher manipulation which appearance is a coarse micro-topography with little holes and depression. In fact, the piece was cleaned with substances able to wash away any greasy surfaces remains; consequently, the polishing was interpreted as the remains of some substance used as an additive to ensure the hafting, more than the result of cinematic action as what is call micro-polish (Keeley, 1980). This kind of polishing is also visible on a small portion of the stem. Under the microscope small black patches were observable in the stems' surface. The LE piece in the blade/stem junction and the abraded borders shows a coarse surface similar to an unwashed piece for microwear studies. These kinds of micro-topography suggest the use of an adhesive. Macroscopically the fishtail point from AC presents a notch-like fracture near the tip. Under the microscope this portion shows an intense polishing different from the rest of the specimen (Figure 4(a)). In the reverse face and also near the fracture, but in the blade and close to the edge, there is an adherence like a yellow paste that might be a substance (Figure 4(b)). Points of similar adherences are also visible in the blade's border. On the shoulder a strong 

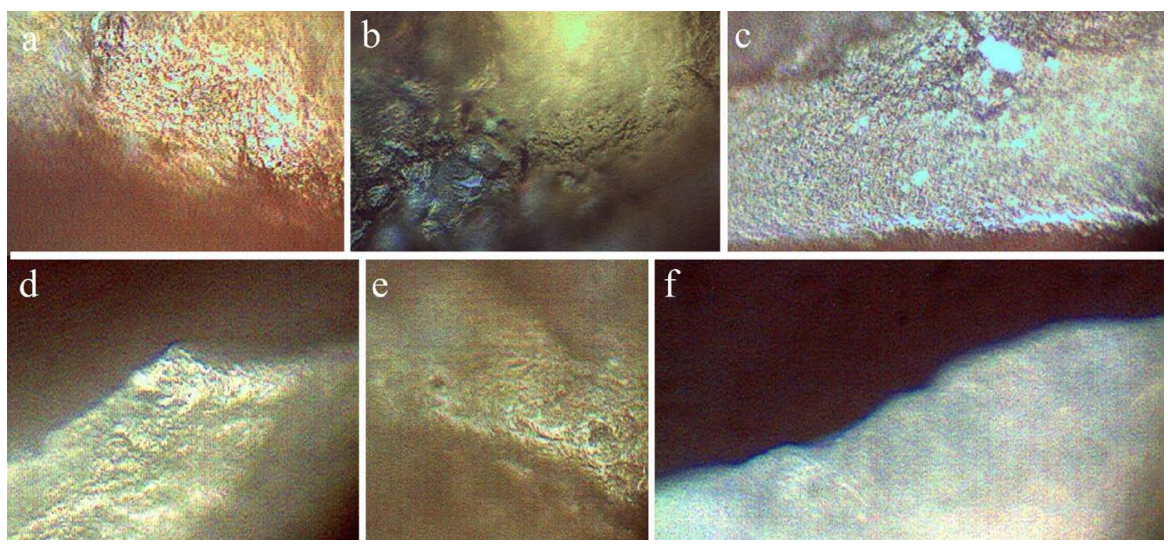

Figure 4. Photomicrographs of the damage observed during microwear analysis. (a)-(c) in the AC fishtail point: (a) polishing; (b) adherence that might be a substance; (c) abrasion; (d)-(f) in the LE biface; (d) edge rounding; (e) abrasion; (f) natural edge.

planar abrasion was observed (Figure 4(c)). As has been reported in previous studies with similar pieces from this site (Nami \& Castro, 2010), on the blade there is abrasion that is not the product of water alteration, such have been observed in the late Pleistocene/early Holocene artifacts from the flowed zone of Los Toldos cave 2 in southern Argentina (Cardich et al., 1993-1994). This abrasive wear is not functional and is the result of the abrasion made for a technological purpose (Sheets, 1973). The LE biface showed a rounded portion (Figure 4(d)) that is brighter on the edge than the rest of the piece but without polishing, probably due to the abrasion used for preparing platforms during its manufacture. The artifact surface seems very fresh and does not show any kind of post depositional alteration; this specimen exhibit naturals edges (Figure 4(f)). Only remnants of platform preparation by abrasion are observed (Figure 4(e)). Hence, this biface was not used. By it size, this piece perfectly fit with an early stage of manufacture of fishtail projectile points, such as has been observed archaeologically and experimentally proposed (Nami, 2001, 2003, 2010).

There is a notably difference between the location of microscopic polishing between the blade and stem in EP and LE points. Polishing in the stem's border might be attributed to leather or a similar substance, probably the leather cord or sinew used to bind the points in the foreshaft. In fact, the leather like polishing is present in the stems and part of the shoulder, suggesting that cordage was used for attaching the point into the foreshaft. Their position suggests that the binding was made where the polishing is observed; in other words, up to the blade-stem junction and shoulder. This fact reinforces previous assessments based on macroscopic observations that edge abrasion on the stems' edges imply that hafting was made to the blade-stem intersection (Nami, 1985-1986, 1987). The surface of the stem shows a coarse micro-topography and has patches of black residues. The coarse micro-topography suggests the use of an adhesive substance covering the whole stem, while the black patches are probably the residue used to glue the points in the foreshafts (Castro, 1993; Rots, 2008).

\section{Concluding Remarks}

In summary, additional observations performed on a number of Paleo-Southamerican lithic artefacts from the Negro river basin allowed adding new light on technology and function of fishtail points; particularly, about its use as projectile heads and the employment of edge-to-edge and/or overshot flaking tactics. In the latter, it is the first report of its existence in this particular Paleo-South American lithic marker from the southern region of South America.

Ongoing research and analysis on more Paleoindian artifacts will add new and complementary data to understand previously unknown technological and functional topics on Late Pleistocene lithic assemblages from southern South America.

\section{Acknowledgements}

We are indebted to the University of Buenos Aires and CONICET for their continuous support; Museo Nacional de Historia Natural y Antropología de Uruguay for having sponsored the archaeological research in Uruguay; A. Toscano, Director of the museum, for his support; A. Florines for his constant support, help, and counsel in dif- 
ferent aspects of this research; S. Bálsamo, C. Alvez, and S. Garrido for their kindness and data about the sites and artefacts; finally to U. Meneghin and J. Femenías (R.I.P.) for providing the photographs illustrated in Figure 3(b) and Figure3(e) respectively.

\section{References}

Bosch, A., Femenías, J., \& Olivera, A. (1980). Dispersión de las puntas líticas pisciformes en el Uruguay. III Congreso Nacional de Arqueología. Anales. Montevideo: CEA.

Callahan, E. (1979). The Basics of Biface Knapping in the Eastern Fluted Point Tradition. A Manual for Flintknappers and Lithic Analysts. Archaeology of Eastern North America, 7, 1-180.

Cardich, A., Paunero, R., \& Castro, A. (1993-1994). Análisis de los Conjuntos Líticos de la Cueva 2 de Los Toldos (Santa Cruz, Argentina), Anales del Instituto de la Patagonia, Serie Ciencias Humanas, 22, 149-173.

Castro, A., (1993). El análisis funcional por medio del estudio microscópico de huellas de uso: Aportes para un modelo de clasificación tipológica. Doctoral Dissertation, La Plata: National University of La Plata.

Cooke, R., \& Sánchez., L. (2003). Panamá prehispánico: tiempo, ecología y geografía política. http://collaborations.denison.edu/istmo/n07/articulos/tiempo.html

Cordero, S. (1960). Los Charrúas. Editorial Mentor, Montevideo.

Keeley, L. H. (1976). Microwear on Flint: Some Experimental Results. 2d International Symposium on Flint, Staringia, 3 , 49-51.

Keeley, L. H. (1980). Experimental Determination of Stone Tool Uses: A Microwear Analysis. London: The University of Chicago Press.

López, F., Femenías, J., \& Nami, H. G. (2001). Fell Evidence and New Data on Late-Pleistocene Landscape from Canelones, Uruguay. Current Research in the Pleistocene, 18, 41-44.

Nami, H. G. (1985/1986). Excavación Arqueológica y Hallazgo de una Punta de Proyectil "Fell I” en la Cueva del Medio, Seno de Ultima Esperanza, Chile. Informe Preliminar. Anales del Instituto de la Patagonia, 16, 103-109.

Nami, H. G (2001). Consideraciones tecnológicas preliminares sobre los artefactos líticos de Cerro de los Burros (Maldonado, Uruguay). Comunicaciones Antropológicas de los Museos Nacionales de Historia Natural y Antropología de Montevideo 3 (1).

Nami, H. G. (2003). Experimentos para explorar la secuencia de reducción Fell de la Patagonia Austral. Magallania, 30, 107-138.

Nami, H. G. (2007). Research in the Middle Negro River Basin (Uruguay) and the Paleoindian Occupation of the Southern Cone. Current Anthropology, 48, 164-176. http://dx.doi.org/10.1086/510465

Nami, H. G. (2009). Crystal Quartz and Fishtail Projectile Points: Considerations on Raw Materials Selection by Paleo-South Americans. Current Research in the Pleistocene, 26, 9-12.

Nami, H. G. (2010). Tecnología Paleoindia de Sudamérica: Nuevos experimentos y observaciones para conocer la secuencia de reducción Fell. Origenes, 9, 1-40.

Nami, H. G. (2013). Archaelogy, Paleoindian Research and Lithic Technology in the Middle Negro River, Central Uruguay. Archaeological Discovery, 1, 1-22. http://dx.doi.org/10.4236/ad.2013.11001

Nami, H. G. (2014). Observaciones para conocer secuencias de reducción bifaciales Paleoindias y puntas Fell en el Valle del Ilaló, Ecuador/Observations pour identifier les séquences de réduction bifaciales paléoindiennes et les pointes de Fell dans la vallée de l'Ilalỏ, Equateur. In M., Farias, \& A. Lourdeau (Eds.), Peuplement de l’Amérique du sud: l'apport de la technologie lithique/Povoamento na América do Sul: a contribuição da tecnologia lítica/Población de América del sur: la contribución de la tecnología lítica. Sociedade de Arqueologia Brasileira XVI Congresso Union Internationale des Sciences Préhistoriques et Protohistoriques Actes du XVI Congrès mundial Florianópolis 4-10/09/2011 @rchéo-éditions.com, In press.

Nami, H. G. \& Castro. A. (2010). New Paleoindian Finds and Micro-Wear Analysis at Arroyo Cacique Site, Tacuarembó Department, Uruguay. Current Research in the Pleistocene, 27, 25-28.

Pearson, G., \& Ream. J. (2005). Clovis on the Caribbean Coast of Venezuela. Current Research in the Pleistocene, 22, 28-30.

Rots, V. (2008). Hafting and Raw Materials from Animals. Guide to the Identification of Hafting Traces on Stone Tools. Anthropozoologica, 43, 43-66.

Sheets, P. D. (1973). Edge abrasIon during Biface Manufacture. American Antiquity, 38, 215-218. http://dx.doi.org/10.2307/279370

Stanford, D. J., \& Bradley, B. (2012). Across the Atlantic Ice. The Origins of American's Clovis Culture. Berkeley: University of California Press. 
Scientific Research Publishing (SCIRP) is one of the largest Open Access journal publishers. It is currently publishing more than 200 open access, online, peer-reviewed journals covering a wide range of academic disciplines. SCIRP serves the worldwide academic communities and contributes to the progress and application of science with its publication.

Other selected journals from SCIRP are listed as below. Submit your manuscript to us via either submit@scirp.org or Online Submission Portal.
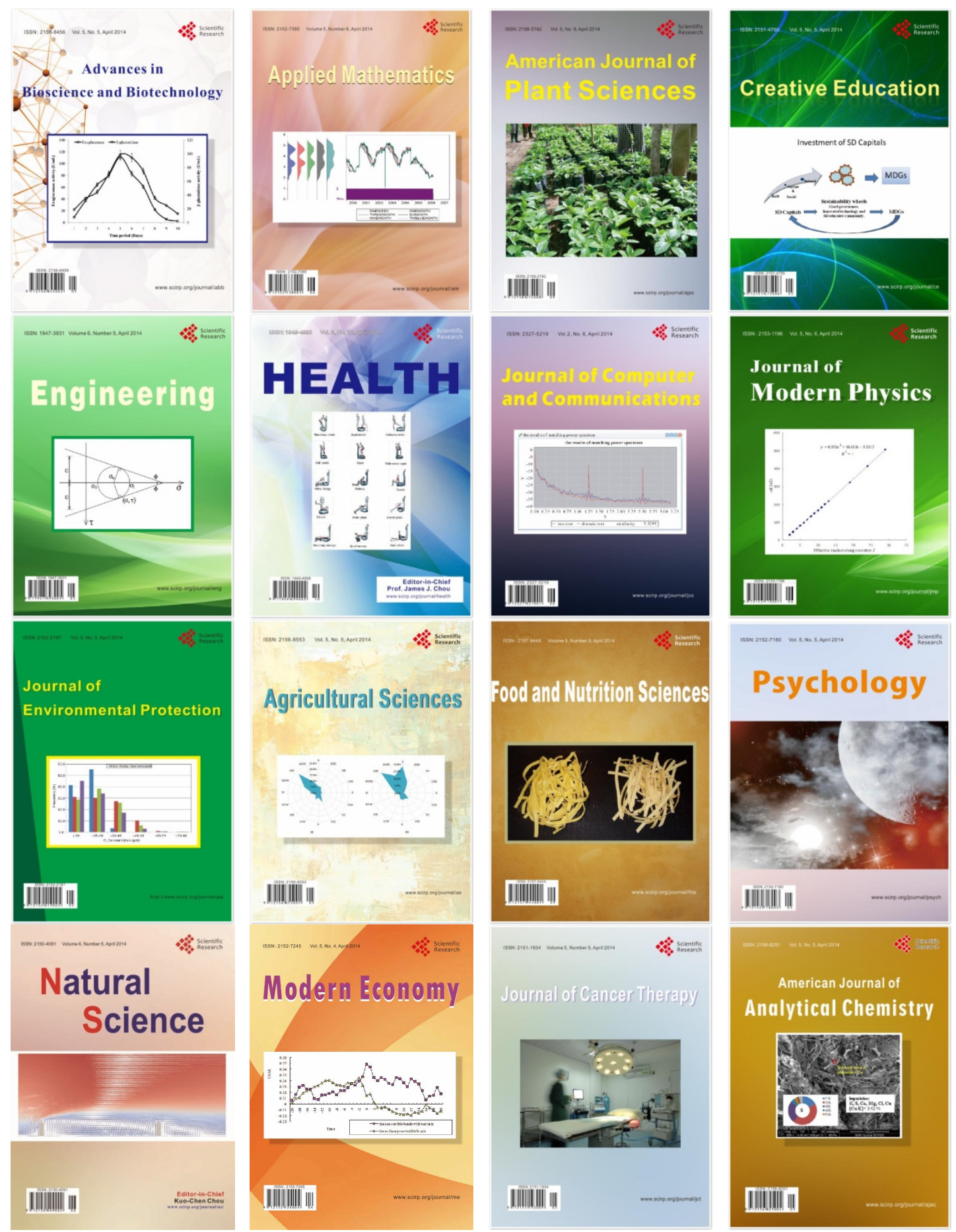